http://ejournal.upi.edu/index.php/jaz - e-mail: jurnal.zonasi@gmail.com dan jurnal_zonasi@upi.edu doi.org/10.17509/jaz.v3i1.22842

\title{
KAJIAN PERILAKU PEJALAN KAKI PADA KAWASAN TRANSIT ORIENTED DEVELOPMENT (TOD)
}

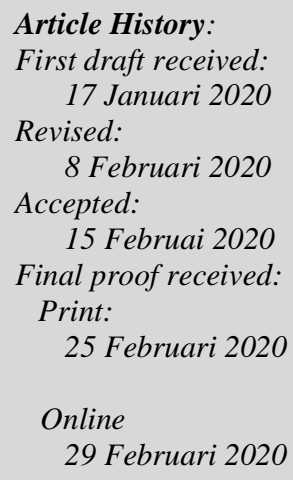

\author{
Taslim Septia Prima ${ }^{1}$; Luthfi Prayogi ${ }^{2}$ \\ 1,2 Universitas Muhammadiyah Jakarta, Jakarta, Indonesia \\ Jl. Cempaka Putih Tengah 27, RT.11/RW.5, Cemp. Putih Tim., Kec. Cemp. Putih, Kota \\ Jakarta Pusat, Daerah Khusus Ibukota Jakarta 10510 \\ Email:2016460047@ftumj.ac.id \\ lutfi.prayogi@ftumj.ac.id
}

\begin{abstract}
Walking is an activity that covers the daily life of the community. Walking can connect from one place to another place. The pedestrian pathway includes facilities that support walking. Especially in the Transit Oriented Development (TOD) area, pedestrian pathways are needed to create people's behavior that likes to walk. Community behavior can be influenced by physical and non-physical factors of the pedestrian path. Different behaviors will produce different responses to the pedestrian path. Some pedestrians will often be bypassed or seen alive, but there are also pedestrians who are not too often traversed so that the path can be said to not be alive.
\end{abstract}

Keywords : Pedestrian, Behavior, Walking

\begin{abstract}
Abstrak: Berjalan kaki termasuk kegiatan yang meliputi keseharian masyarakat. Berjalan kaki dapat menghubungkan dari suatu tempat ke tempat lainnya. Jalur pedestrian termasuk fasilitas yang mendukung kegiatan berjalan kaki. Terutama dalam Kawasan Transit Oriented Development (TOD), jalur pedestrian sangat dibutuhkan guna menciptakan perilaku masyarakat yang senang berjalan kaki. Perilaku masyarakat dapat dipengaruhi oleh faktor fisik maupun non fisik dari jalur pedestrian. Perilaku yang berbeda beda akan menghasilkan respon yang berbeda pada jalur pedestrian. Beberapa pedestrian akan sering dilewati atau terlihat hidup namun ada juga pedestrian yang tidak terlalu sering dilewati sehingga jalur tersebut dapat dikatan tidak hidup.
\end{abstract}

Kata Kunci: Pedestrian, Perilaku, Berjalan Kaki

\section{Pendahuluan}

Berjalan kaki adalah kegiatan yang selalu dilakukan manusia di kesehariannya. Berjalan kaki memudahkan manusia dalam berpindah tempat dari satu tempat ke tempat lainnya. Salah satu fasilitas yang dibutuhkan oleh pejalan kaki yaitu jalur pedestrian, jalur ini tercipta karena tingginya tingkat pejalan kaki di dalam kota yang membutuhkan tempat untuk melampiaskan perjalanannya. Kadang pula jalur pedestrian digunakan sebagai konektivitas antara bangunan menuju kendaraan umum. Keduanya memiliki sinergisitas dalam membangun kehidupan masyarakat yang mulus.

Dalam melakukan perjalanan membutuhkan tempat yang dituju dan sarana yang akan digunakan untuk menuju tempat tersebut. Sarana transportasi menjadi salah satu sarana yang paling banyak digunakan oleh masyarakat. Sarana transportasi mempermudah masyarakat dalam melakukan aktivitas sehari hari. Transportasi tersebut memiliki banyak jenis, seperti mobil, sepeda motor, kereta api, sepeda, busway, metro mini, kendaraan online, Mass Rapid Transit (MRT), Light Rapid Transit (LRT) dan lain lain. Kendaraan tersebut banyak sekali ditemukan di dalam suatu kota, Namun, lebih mudah dalam menemukan semuanya dalam suatu Kawasan tertentu yang telah menerapkan konsep Transit Oriented Development (TOD). Konsep ini sudah banyak diterapkan oleh berbagai negara negara maju. Tujuannya adalah agar trasportasi lebih dapat 
dijangkau masyarakat serta menumbuhkan rasa ingin menggunakan transportasi umum dibandingkan kendaraan pribadi yang dapat meningkatkan kapasitas jalanan kota sehingga menimbulkan kemacetan.

Perilaku manusia yang berada di Kawasan TOD dan Kawasan biasa juga memiliki beberapa perbedaan. Terutama dalam pemanfaatan kendaraan umum dan kesehatan lingkungan maupun masyarakat, bagi Kawasan yang telah menerapkan TOD tidak harus khawatir akan terjadinya kemacetan, karena hal itu sudah di pelopori oleh rasa keinginan masyarakat dalam menggunakan transportasi umum sehingga polusi udara lebih sedikit dan masyarakat lebih senang berjalan kaki untuk kesehatan individu, bagi Kawasan yang tidak menerapkan TOD cenderung terlibat kemacetan, karena masyarakat terpaksa mengeluarkan kendaraan umum karena lokasi dari sarana transportasi yang jauh dari tempat tinggal, setelah itu banyaknya pedestrian yang terbuat sia sia karena populasi pejalan kaki yang lebih sedikit dibandingkan Kawasan TOD. Dalam menyikapi Kawasan TOD masyarakat dibuat menjadi lebih mandiri dan dimanjakan dengan keadaan yang mereka inginkan, contohnya di beberapa negara yang menerapkan mixed use salah satu dari konsep TOD tersebut sehingga masyarakat yang berjalan kaki dapat menghibur diri dengan mengunjungi beberapa toko keperluannya.

Saat ini perilaku manusia juga menjadi tolak ukur dalam pemenuhan keinginan manusia dalam beraktivitas. Kegiatan ini yang membuat Kawasan TOD melakukan beberapa perubahan yang didasari oleh keinginan dan kebutuhan manusia saat ini maupun di hari kemudian. Moda transportasi yang kian hari kian banyak tetap membutuhkan fasilitas fasilitas khusus guna untuk memanjakan manusia dalam berjalan kaki menuju destinasi selanjutnya. Keadaan tersebut mendorong Kawasan TOD sebagai Kawasan yang peduli terhadap perilaku manusia yang didukung dengan seting seting tempat yang dipergunakan sebagai proses menuju destinasi selanjutnya.

1. Apa faktor yang mempengaruhi perilaku masyarakat dalam berjalan kaki di Kawasan Transit Oriented Development (TOD) ?

2. Bagaimanakah fisik lingkungan binaan mempengaruhi perilaku masyarakat pejalan kaki yang melewati Kawasan Transit Oriented Development (TOD)?

Arsitektur perilaku adalah hubungan antara rancangan dengan kegiatan kegiatan yang dipengaruhi oleh rancangan tersebut yang dapat mempengaruhi psikologis dari penikmatnya. Kata perilaku menunjukkan aktivitas manusia secara fisik yang mana dapat dilakukan ke sesamanya ataupun lingkungan fisik (Anthonius N. Tandal, 2011) .

Dalam arsitektur perilaku terdapat Manusia dan lingkungan yang merupakan dua faktor penting yang terus berkaitan dan saling mempengaruhi, perilaku manusia dapat merubah lingkungannya dan lingkungan sendiri dapat merubah perilaku manusia (Nuqul, 2005). Pengaruh perilaku dapat terjadi seperti berikut ini :

1. Lingkungan dapat menghalangi perilaku seperti adanya tembok yang menjadi pembatas sehingga membatasi pergerakan yang ada

2. Lingkungan dapat mendatangkan perilaku, seperti saat ada orang di dalam masjid dan dia tidak ingin membuat kebisingan karena berada di tempat yang suci.

3. Lingkungan dapat membentuk diri, lingkungan yang selalu berada dalam keseharian dapat menjadi faktor tumbuh kembang diri di masa yang akan datang.

4. Lingkungan memperngaruhi citra diri, ini adalah pengaruh yang dilihat melalui setting orang yang berada di dalamnya, seperti gembel yang merasa dirinya rendah karena berada di tempat yang kumuh.

\subsection{Perilaku Pejalan Kaki}

Pejalan kaki dalam kesehariannya berpindah pindah dari suatu tempat ke tempat lainnya menggunakan kakinya sebagai alat transportasinya (Widodo, 2001) Berjalan kaki juga diiringi oleh berbagai kegiatan yang dilakukan oleh pejalan kaki, misalnya dengan saling berdiskusi, bermain gadget dan lain lain. Berjalan kaki dengan kecepatan rendah memberikan keuntungan bagi para penikmatnya, yaitu dapat mengamati lingkungan secara detail dan merasakan lingkungan sekitar (Widodo, 2001).

Pedapat lain juga dinyatakan oleh Gideon Geovani (1977) yaitu dengan berjalan dapat menghubungkan beranekaragam fungsi Kawasan terutama Kawasan perdagangan, Kawasan budaya dan Kawasan permukiman (Widodo, 2001). Menurut Spreiregen (1965) pejalan kaki bebas dalam menentukan langkahnya, berhenti, berbelok dan bebas mengatur kontak dengan lingkungan sekitarnya, sehingga berjalan kaki bukan hanya moda transportasi namun juga sebagai komunikasi sosial masyarakat (Widodo, 2001).

Sedangkan Menurut (Siti Nurjanah Ahmad, 2013) kegiatan berjalan kaki dilakukan oleh masyarakat di pinggir jalan karena sering terjadinya konflik antara pengendara dan pejalan kaki. Oleh karena itu prioritas utama adalah melihat apakah sudah tersedia fasilitas fasilitas untuk mendukung pejalan kaki dan perawatan pada fasilitaas fasilitas tersebut. Adapun bentuk bentuk pejalan kaki adalah sebagai berikut :

Spreiregen (1965) mengungkapkan berjalan kaki adalah sesuatu yang sangat baik walaupun memiliki keterbatasan yaitu kecepatannya sekitar 3 - 4 km/jam dan daya jangkaunya tergantung oleh fisik pejalan kaki 
(Widodo, 2001). Menurut Uterman (1984) (Widodo, 2001) 3 faktor penting yang mempengaruhi jarak tempuh pejalan kaki, yaitu :

1. Waktu, kegiatan yang akan dilakukan dengan berjalan kaki tergantung pada waktu waktu kepentingan pejalan kaki. Disaat kepentingan berjalan kaki untuk berekreasi maka waktu yang ditempuh akan relatif lama tetapi apabila kepentingan berjalan kaki ingin menuju tempat bekerja yang berbatas waktu maka butuh pertimbangan dalam memikirkan jarak tempuhnya.

2. Kenyamanan, kenyamanan pejalan kaki dapat berasal dari kondisi cuaca dan jenis kegiatan yang akan dilakukan. Iklim yang panas dapat mempengaruhi minat para pejalan kaki untuk melangsungkan aktivitasnya dengan berjalan kaki begitu juga sebaliknya.

3. Ketersediaan kendaraan bermotor, ketersediaan fasilitas kendaraan pribadi menguntungkan pejalan kaki dalam menempuh perjalanan yang relatif jauh sehingga kegiatan berjalan kaki dapat dilakukan setelah kendaraan diparkirkan.

Menurut (Siti Nurjanah Ahmad, 2013) fasilitas yang mendukung untuk memperoleh kenyamanan para pejalan kaki meliputi : adanya street furniture, pohon yang rindang, Street desk, kontinuitas pedestrian, jembatan penyeberangan. Menurut (Rona Panduri, 2015) faktor faktor yang mempengaruhi jarak tempuh berjalan kaki adalah :

1. Waktu

2. Kenikmatan

3. Kemudahan berkendara

4. Pola penggunaan lahan

\subsection{Faktor Faktor yang Mempengaruhi Pejalan Kaki}

Dari pembahasan di sub bab sebelumnya dapat disimpulkan bahwa terdapat beberapa hal yang mempengaruhi perilaku pejalan kaki. Adapun faktor tersebut dibagi menjadi 2 yaitu faktor lingkungan dan faktor jarak tempuh pejalan kaki. Faktor yang dipengaruhi oleh lingkungan, antara lain :

1. Pembatas, dengan adanya tembok besar yang menghalangi jalan membuat perilaku pergerakan pejalan kaki terbatas.

2. Temperatur, suhu yang panas dapat menjadi alasan bagi para pejalan kaki tidak melintasi jalur pedestrian yang ada karena faktor penghijauan yang ada di sekitar jalur pedestrian yang kurang memadai.

3. Polusi Udara, debu maupun asap kendaraan yang terpapar langsung ke area jalur pedestrian dapat mengurangi kenyaman pejalan kaki.

4. Kebisingan, jalan yang sempit menimbulkan kemacetan dijalan dan memberikan efek kebisingan apabila tidak adanya sekat antara jalan dan jalur pedestrian.

5. Kepadatan, Jalur pedestrian yang sempit dan tidak sesuai dengan jumlah penggunanya setiap harinya akan berdampak dengan ketidaknyaman pejalan kaki karena harus berdesakan hingga mengantri disepajang jalan.

Adapun faktor yang dipengaruhi oleh jarak tempuh pejalan kaki antara lain:

1. Waktu, kepentingan dalam berjalan kaki mempengaruhi waktu para pejalan kaki. Apabila berjalan kaki menuju ke tempat kerja yang berbatas waktu maka waktu berjalan kaki relatif cepat, sebaliknya apabila pejalan kaki bertujuan untuk rekreasi maka waktu berjalan kaki akan relaatif lama.

2. Kenyamanan, kenyamanan dalam berjalan kaki juga dipengaruhi oleh lingkungan yang ada serta kondisi dari pejalan kaki. Adapun kondisi jalur pejalan kaki akan berfungsi baik untuk kenyamanan pejalan kaki yang meliputi :

a. Kelancaran, semakin mudahnya rute yang ditempuh pejalan kaki maka akan meningkatkan minat pejalan kaki.

b. Jarak/Lama/Panjang, jalur pejalan kaki tidak boleh terlalu Panjang dan menimbulkan banyak ruang kosong, karena akan sulit untuk membentuk kontak sosial antar pejalan kaki.

c. Lebar/Keluasan, berjalan kaki dapat dirasakan kenikmatannya saat dilakukan Bersama sama oleh karena itu lebar jalur pejalan kaki harus bisa menampung 2 orang atau lebih.

3. Fasilitas Kendaraan, dengan adanya parkir yang jauh dari tempat bekerja akan membuat pengendara dapat merasakan berjalan kaki setelah kendaraan diparkirkan.

\subsection{Jalur Pedestrian}

Jalur pedestrian adalah jalur bagi pejalan kaki yang terletak lebih tinggi dibandingkan jalan utama lalu lintas serta sejajar dan dibuat dari permukaan perkerasan jalan (Rini Darmawant, 2011). Berjalan kaki adalah salah satu kegiatan manusia sehari hari dalam berpindah dari suatu tempat ke tempat lainnya. Dengan berjalan kaki keindahan suatu kota dapat dilihat dengan detail dan indah diwaktu yang bersamaan (Indraswara, 2006). 
Orang orang yang melakukan kegiatan berjalan kaki disebut pejalan kaki. Salah satu media dalam berjalan kaki adalah jalur pedestrian. Menurut Shirvani (1985) mengatakan bahwa pejalan kaki membutuhkan jalur pedestrian. Yang mana adalah salah satu elemen keberhasilan perancangan dalam suatu Kawasan kota. Pedestrian juga disebut sebagai sirkulasi atau pergerakan manusia dari tempat asal (Origin) menuju tempat yang diinginkan (destination) dengan berjalan kaki (Hantono, Butudoka, Prakoso, dan Yulisaksono, 2019).

Menurut Shirvani (1985) bahwa jalur pejalan kaki merupakan salah satu yang menjadi pertimbangan dalam perencanaan kota. Sistem jalur pedestrian yang baik akan merangsang pedagang eceran, mengurangi penggunaan kendaraan bermotor, meningkatkan kualitas lingkungan dan udara serta mengurangi polusi udara (Widodo, 2001). Menurut David Sucher (1995) (Widodo, 2001) jalur pejalan kaki akan berfungsi baik untuk kenyamanan pejalan kaki dengan menaati peraturan peraturan berikut :

1. Kelancaran, dalam berjalan kaki semakin tidak sulitnya rute yang ditempuh maka perjalanannya akan meningkatkan antusias dalam berjalan kaki.

2. Jarak/Lama/Panjang, jalur pejalan kaki tidak boleh terlalu Panjang sehingga pejalan kaki dapat bertemu dengan pejalan kaki lainnya dan membuat kontak sosial.

3. Lebar/Keluasan, pejalan kaki sangat senang melakukan perjalanan Bersama sama sehingga lebar dari jalur pejalan kaki harus bisa menampung 2 orang atau lebih.

Menurut Gideo Giovany (1977) bahwa berjalan kaki merupakan sarana transportasi yang menghubungkan antara fungsi kawasan satu dengan yang lain terutama kawasan perdagangan, kawasan budaya, dan kawasan permukiman, dengan berjalan kaki menjadikan suatu kota menjadi lebih manusiawi. Namun, tidak semua jalur pedestrian digunakan sebagaimana mestinya. Masih banyak jalur pedestrian yang malah digunakan sebagai tempat berjualan bahkan sepi pejalan kaki. Ini terjadi bukan hanya karena jalan tersebut tidak memiliki banyak ketertarikan, tetapi beberapa penataan dari sirkulasi kendaraan umum yang tidak menyambungkan antara pedestrian tersebut dengan jalur keluar kendaraan umum yang dibutuhkan. Bukan hanya itu, banyak pula jalur jalur pedestrian yang tidak sesuai dengan ukuran bagi banyak pejalan kaki sehingga memiliki ruang yang kecil dan sempit saat di akses oleh pejalan kaki (Ischak, Setioko, dan Gandarum, 2018).

Berdasarkan hasil penelitian Gota, dkk (2010) yang berjudul "Walkability Surveis in Asian Cities", Jakarta sebagai ibukota sekaligus kota terbesar di Indonesia masuk dalam kategori yang tidak walkable atau tidak ramah untuk kegiatan berjalan kaki. Di Indonesia secara umum dan Jakarta khususnya masalah pedestrian adalah masalah yang belum dapat di atasi secara tuntas. Ini semua terjadi karena perencanaan pedestrian sebagai bagian dari elemen sebuah kota tidak saling berkaitan dengan elemen kota lainnya sehingga aksesibilitas dalam mencapai tujuan dengan mudah dengan berjalan kaki sangatlah sulit. (Sudhir Gota, 2010)

\subsection{Kawasan Transit Oriented Development (TOD)}

Transit Oriented Development (TOD) adalah konsep pengembangan kawasan di dalam lokasi transit agar bernilai tambah yang berpusat pada integrasi antara jaringan angkutan umum massal dengan jaringan moda transportasi tidak bermotor, serta pengurangan penggunaan kendaraan bermotor yang disertai pengembangan kawasan campuran dan padat dengan intensitas pemanfaatan ruang sedang hingga tinggi. (Permen ATR/BPN No. 16 tahun 2017). Transit Oriented Development (TOD) juga merupakan konsep pengembangan atau pembangunan kota yang memaksimalkan penggunaan lahan yang bercampur dan terintegrasi dengan mempromosikan gaya hidup yang sehat (berjalan kaki dan bersepeda) dan penggunaan angkutan umum massal (TODguidebook, 2006).

TOD dikenalkan pertama kali oleh Peter Calphore pada tahun 1993, beliau menyatakan bahwa TOD merupakan pengembangan suatu titik dalam suatu perkotaaan yang mana berada di lokasi transit transportasi umum dengan memaksimalkan penggunaan pedestrian dan kegiatan berjalan kaki agar dapat mengurangi penggunaan kendaraan pribadi. Dengan menerapkan konsep ini masyarakat dituntut untuk mau berjalan kaki dan menggunakan pedestrian sebagai elemen utama dalam berpergian (Siregar, 2015). Namun tuntutan juga berpengaruh terhadap pihak pihak perancang konsep ini. Pihak perancang dirasa harus dapat membuat rancangan yang membuat masyarakat tertarik untuk melakukan kegiatan berjalan kaki yang mana dalam penciptaanya membutuhkan adaptasi yang begitu lama agar menjadi kebiasaan yang positif.

Tujuan dari penelitian ini adalah sebagai berikut :

1. Mengidentifikasi keinginan pejalan kaki terhadap Kawasan Transit Oriented Development (TOD).

2. Menganalisis fisik lingkungan binaan yang tepat guna meningkatkan antusias pejalan kaki.

3. Menjelaskan sikap dan perilaku pejalan kaki dalam memanfaatkan Kawasan Transit Oriented Development (TOD). 


\section{Metode Penelitian}

Metode penelitian ini menggunakan metode kualitatif. Metode kualitatif adalah metode yang menitikberatkan pada sebuah deskripsi dan analisis, yang mana deskripsi dan analisis ini dapat diteliti menggunakan indra penglihatan. Metode ini pun didukung oleh teori teori yang berhubungan dengan penelitian ini agar penelitian semakin teruji dan terarah. Pemilihan metode ini dilatarbelakangi penulis dalam melakukan penelitian guna memberikan pengetahuan tentang hal-hal yang belum banyak diketahui, yang mana dalam kasus ini berjudul kajian Perilaku Pejalan Kaki Pada Kawasan Transit Oriented Development (TOD).

Pendekatan yang dipilih oleh penulis dalam penelitian ini adalah pendekatan Deskriptif. Pendekatan deskriptif sendiri adalah pendekatan yang mendeskripsikan fenomena yang terjadi secara akurat dan faktual. Dengan pedekatan ini, penulis dapat lebih memfokuskan dalam menganalisis masalah dari penelitian pengaruh Kawasan TOD terhadap perilaku pejalan kaki dengan melihat kenyataannya di lapangan.

\section{Hasil dan Pembahasan}

\subsection{Kowloon, Hongkong}

Kowloon, Hongkong terletak di bagian selatan Hongkong dekat dengan laut Hongkong. Keberadaan kota ini sangatlah dibutuhkan oleh masyarakat Hongkong karena di dalamnya telah menerapkan konsep TOD dan terdapat banyak pejalan kaki yang mana menjadi objek dari penelitian ini. Kowloon termasuk kota yang sudah sangat modern karena seluruh kota dikelilingi oleh bangunan bangunan tinggi yang dapat diakses dengan seluruh kendaraan umum serta keberadaan masyarakatnya yang bertempat tinggal di apartemen terdekat.

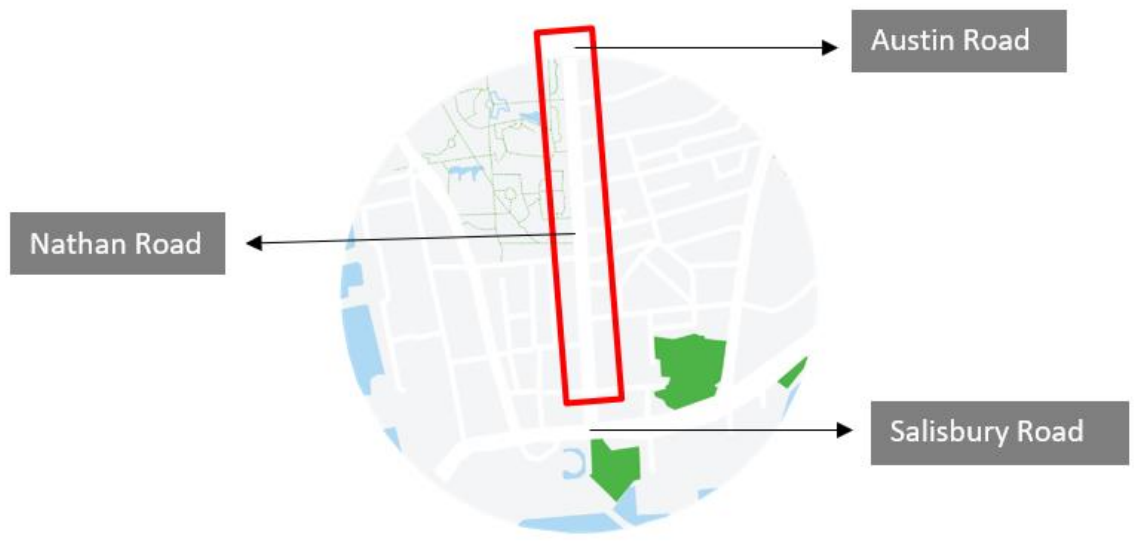

Gambar 1. Peta Kawasan Kowloon, Hongkong

Sumber : Data Peneliti

Dalam penilitian kali ini, peneliti membagi objek yang diteliti menjadi 3 ruas, yaitu ruas a,b dan c yang mana berada di Nathan Road yang dibatasi oleh persimpangn Salisbury Road dan Austin Road.

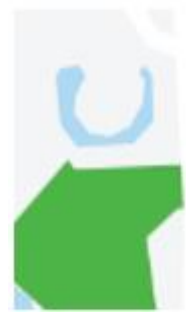

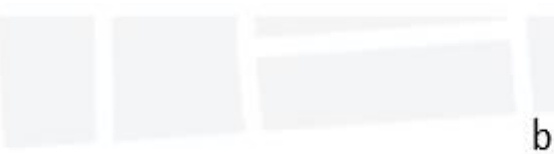

$\mathrm{C}$

b

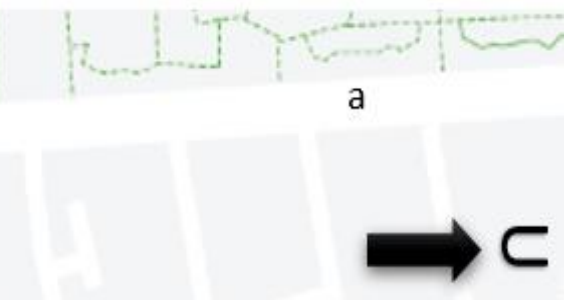

Gambar 2. Ruas Ynng Diteliti

Sumber : Data Peneliti

Adapun data dari tiap ruas ruas tersebut adalah sebagai berikut :

Ruas a 
Timur :

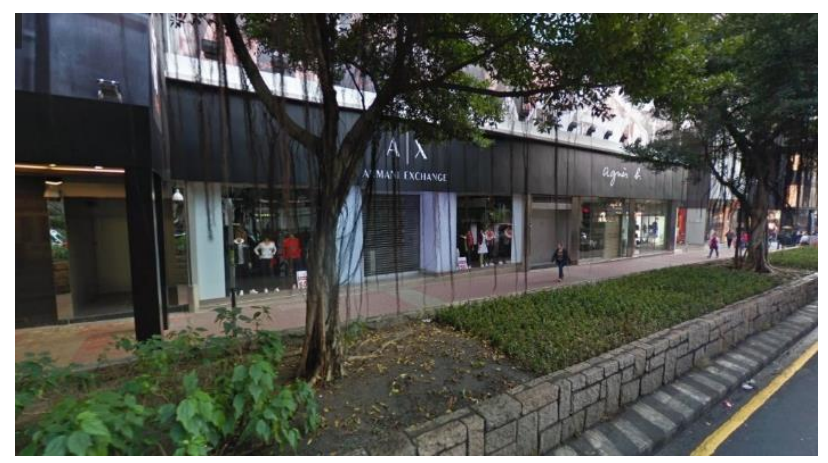

Gambar 3. Pemandangan Ruas a

Sumber : Data Peneliti

Ruaa a pada jalur pedestrian yang ada di sebelah Timur memiliki naungan yang begitu banyak yaitu melalui pohon dan Gedung. Sedangkan pada jalur pedestrian yang ada di sebelah Barat memiliki naungan yaitu Gedung 2 lantai dan pohon tetapi dengan lebar dari pedestrian yang cukup besar membuat bagian yang ternaungi hanyalah bagian pinggirnya saja. Berdasarkan aspek ukuran lebar pedestrian sebelah timur hanya mencapai 3 meter Sedangkan jalur pedestrian sebelah barat memiliki lebar yang cukup besar yaitu 8 meter.

Kecepatan pejalan kaki pada jalur pedestrian sebelah timur memiliki kecepatan yang beragam, beberapa orang bergerak lambat untuk melihat barang barang yang ada di dalam persil dan beberapa lainnya bergerak cepat untuk menuju tempat kerja. Sedangkan pada pedestrian sebelah barat Pejalan kaki terlihat lebih santai dan tidak terlalu banyak. Di lain sisi pada pedestrian sebelah barat dan timur sama sama dibatasi pepohonan antara jalur pedestrian dan jalan utama pembatas itu berbentuk taman kecil dengan lebar 2 meter yang terdapat pohon di tengahnya. Adapun bentuk potongan dari pedestrian tersebut adalah sebagai berikut.

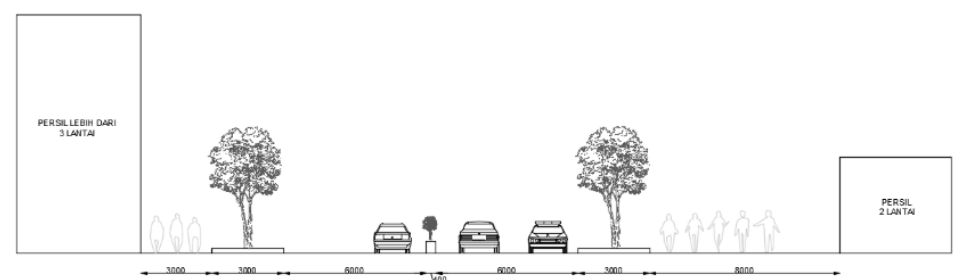

LOKASI a

Gambar 4. Potongan Ruas a

Sumber : Data Peneliti

Ruas b

Timur :

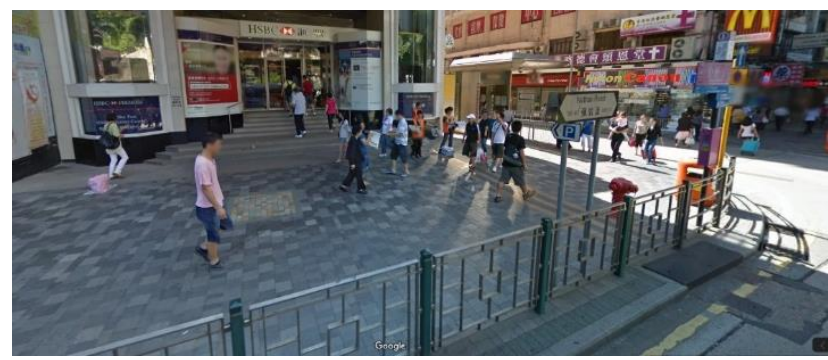

Barat :

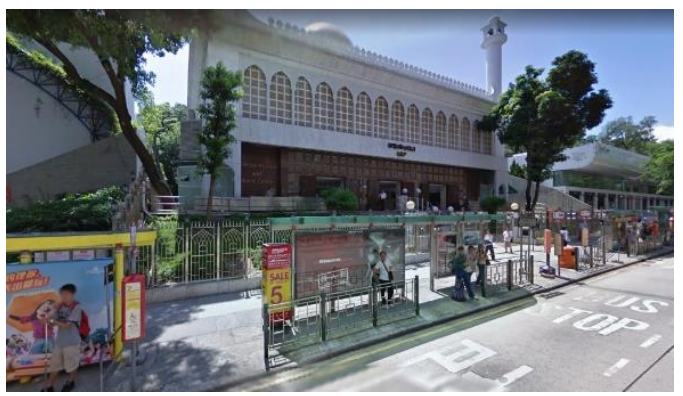

Gambar 5. Pemandangan Ruas b

Sumber : Data Peneliti

Pada jalur pedestrian yang ada di sebelah timur memiliki naungan yaitu Gedung yang tepat berada di samping dari pedestrian itu sendiri .Sedangkan pada pedestrian yang ada di sebelah barat Gedung dengan pedestrian terdapat jarak dan Gedung tersebut tidak terlalu ting gi dan jalur yang dilalui sangat panas di siang 
hari tetapi terdapat halte untuk menunggu bus dan berteduh masyarakat. Untuk ukuran jalur pedestrian, pada pedestrian sebelah timur memiliki lebar 5 meter sedangkan pedestrian sebelah barat hanya memiliki lebar 3 meter.

Jalur pedestrian sebelah timur menyiapkan pagar untuk menjadi batas jalur pedestrian sedangkan pada pedestrian sebelah barat tidak diberi pagar karena terletak beberapa halte yang digunakan untuk menaikkan penumpang menuju busway. Kedua sisi memliki kecepatan pejalan kaki yang berbeda dan peminat yang berbeda. Pada jalur pedestrian sebelah timur kecepatan pejalan kaki cenderung cepat yaitu $2 \mathrm{~m} / \mathrm{s}$.pedestrian tersebut dekat dengan berbagai tempat bekerja dan banyak dilalui oleh pegawai tetapi ada kalanya kecepatan pejalan kaki berubah ubah karena ingin melihat barang dagangan persil . kecepatan pejalan kaki pada jalur pedestrian sebelah timur.

Pada ruas $b$ terdapat jalur pedestrian yang cukup besar beserta persil yang berada di sepanjang jalur pedestrian. Persil persil ini mampu menarik perhatian para pejalan kaki sehingga memperlambat gerakannya hanya untuk melihat dan merubah pikiran untuk masuk atau tidaknya ke dalam persil. Dengan lebar jalur pedestrian yang besar membuat kepadatan tidak berujung akan kemacetan sehingga masyarakat yang memperkecil kecepatannya dapat berhenti sejenak untuk berpikir kembali dan masyarakat yang memiliki kepentingan lain dapat melanjutkan perjalanannya melalui sisi yang kosong. Kecepatannya dapat dilihat seperti gambar di bawah ini.

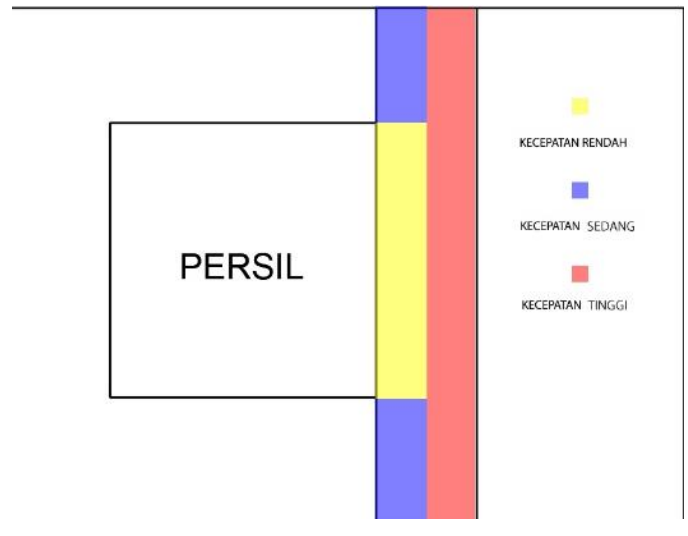

\section{Gambar 6. Kecepatan Pejalan Kaki Ruas b sebelah timur}

Sumber: Data Peneliti

Gambar ini menyimpulkan bahwa fasilitas persil menjadi pengaruh dalam perubahan kecepatan pejalan kaki. Walaupun begitu lebar jalur pedestrian yang besar dapat menjadi solusi agar tidak terjadinya kepadatan yang terlalu besar.

Sedangkan pada jalur pedestrian sebelah barat terdapat masjid terbesar di Kowloon dan jalur tersebut adalah terusan dari taman Kowloon. Para pejalan kaki dari jalur ini adalah para jamaah masjid dan wisatawan. Adapun potongan pada jalur pedestrian ini adalah sebagai berikut.

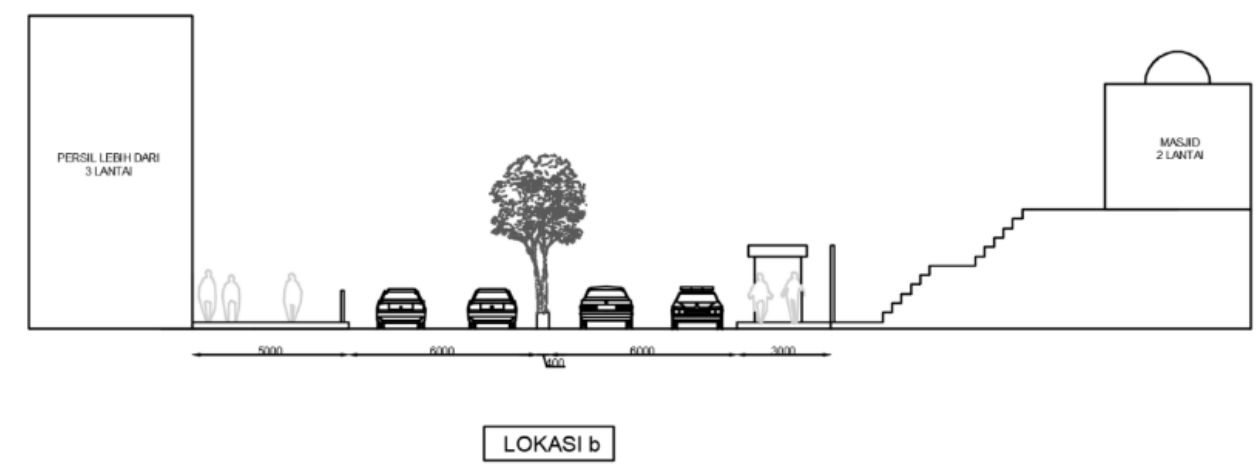

Gambar 1. Potongan Ruas b

Sumber: Data Peneliti 
Ruas c

Timur :

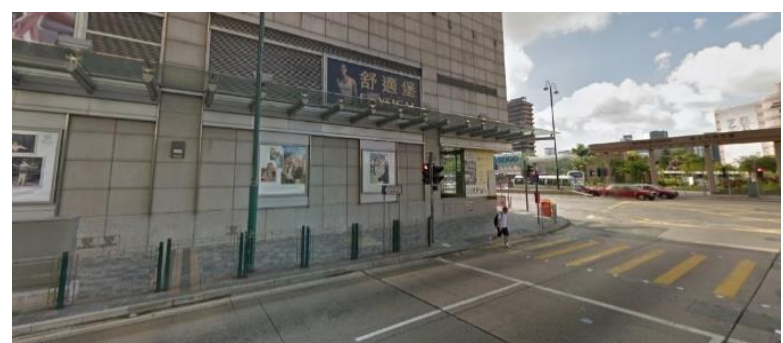

Gambar 2. Pemandangan Ruas c

Sumber: Data Peneliti

Jalur pedestrian ini adalah jalur pedestrian tersibuk dari jalur pedestrian lainnya. Keduanya sama sama memiliki naungan Gedung. Selain itu ukuran dari pedestrian pun sama yaitu 4 meter yang mana selalu dilalui oleh para pekerja dan. Tidak ada yang membatasi kedua jalur pedestrian. Tidak adanya pepohonan di sekitar kedua jalur pedestrian ini.

Kecepatan di kedua jalur pedestrian ini relative sama yaitu $2 \mathrm{~m} / \mathrm{s}$ pada saat biasanya tetapi pada jalur pedestrian bagian sebelah barat terdapat jalur masuk menuju stasiun MTR membuat kecepatan dan kepadatannya bagi yang ingin memasuki stasiun MTR berbeda dengan jalur sebelah timur. Mereka berjalan lebih cepat untuk memasuki stasiun MTR.

Kecepatan pejalan kaki tiap orang berbeda beda karena kepentingan yang berbeda pula. Contohnya pada Kawasan Kowloon jalur pedestrian ruas c. pada jalur pedestrian tersebut terdapat pintu masuk menuju stasiun MRT sehingga setiap orang yang ingin memasuki pintu masuk tersebut berjalan terburu buru sedangkan orang disekitar yang tidak ingin memasuki stasiun MRT hanya berjalan seperti biasanya bahkan bisa lebih lambat.

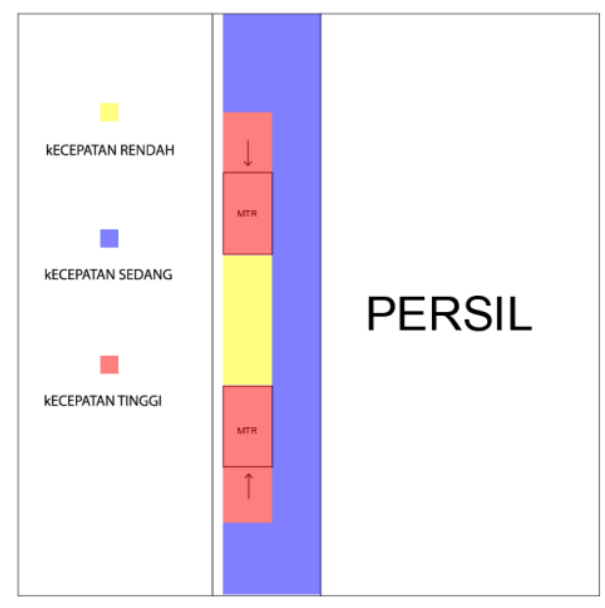

\section{Gambar 3. Kecepatan Pejalan Kaki Ruas c}

Sumber : Data Peneliti

Keadaan tersebut menyimpulkan bahwa perubahan kecepatan pejalan kaki juga dapat dipengaruhi oleh fasilitas fasilitas transportasi. Adapun potongan dari kedua jalur pedestrian ini adalah sebagai berikut.

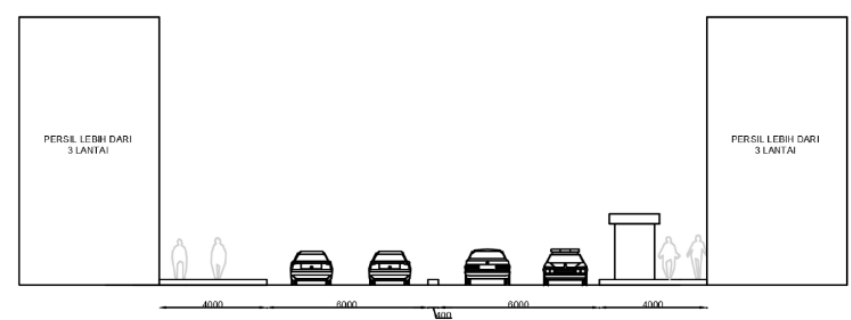

Gambar 4. Potongan Ruas c

Sumber : Data Peneliti 
Naugan termasuk salah satu faktor yang mempengaruhi kecepatan para pejalan kaki. Tak jarang pejalan kaki berteduh pada naungan agar terhindar dari cuaca yang sangat panas maupun hujan yang berkelanjutan. Keberadaan naungan di berbagai jalur pedestrian dirasa penting untuk mempengaruhi kecepatan para pejalan kaki.

Jalur pedestrian yang memiliki naungan di sepanjang jalur ada pada Kawasan Kowloon. Naungan berada di seluruh ruas yang diteliti.

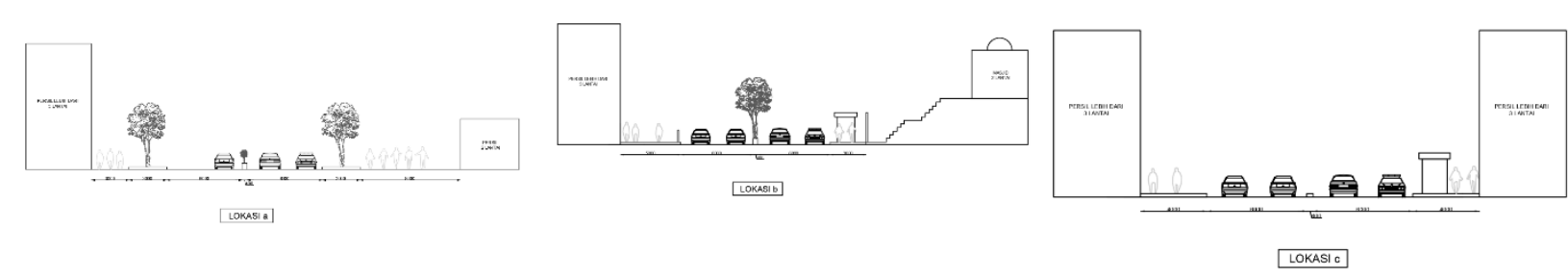

Gambar 5. Potongan Ketiga Ruas Kawasan Kowloon

Sumber : Data Pribadi

Pada gambar di atas semua memiliki naungan Gedung dan beberapa memiliki naungan pohon. Naungan pohon Bersama naungan Gedung jika dikolaborasikan akan menimbulkan kenyamanan yang tinggi di jalur pedestrian seperti pada lokasi a. lokasi lainnya walaupun tidak mendapatkan naungan pohon masih memiliki naungan Gedung yang mana juga dapat menaungi masyarakat dari panas saat siang hari. Tetapi pada lokasi $b$ naungan bukan didapatkan dari naungan Gedung tetapi naungan dari halte halte yang banyak tersedia di depan masjid Kowloon. Hawa yang diciptakan dari naungan akan membuat masyarakat tidak kepanasan dan kelelahan saat berjalan di area jalur pedestrian sehingga kecepatan pejalan kaki akan relatif melambat. Naungan menjadi penting untuk dimiliki oleh jalur pedestrian.

\section{Kesimpulan}

Arsitektur perilaku para pengguna jalur pedestrian pada Kawasan Transit Oriented Development (TOD) banyak sekali dipengaruhi oleh berbagai banyak faktor. Perilaku masyarakat dalam berjalan kaki merupakan salah satu pendukung jalur pedestrian untuk dapat dilewati masyarakat sehingga menjadi jalur pedestrian yang hidup. Beberapa faktor dapat mempengaruhi perilaku masyarakat tersebut dalam melakukan kegiatan berjalan kaki. Faktor faktor tersebut seperti naungan, cuaca, fasilitas, pembatas dan yang dipengaruhi dari perilaku tersebut berupa kecepatan pejalan kaki.

Lingkungan fisik sangat berperan dalam mempengaruhi perilaku pejalan kaki pada Kawasan TOD. Beberapa lingkunngan fisik yang berperan antara lain seperti naungan, pembatas, dan fasilitasyang dapat mempengaruhi kecepatan pejalan kaki,. Faktor tersebut dapat menimbulkan perilaku yang berbeda beda sehingga masyarakat dapat menghidupkan jalur pedestrian yang ada.

Peranan jalur pedestrian dalam melengkapi keseharian pejalan kaki seringkali menimbulkan kenyamanan dan tidaknyamanan pejalan kaki. Disaat jalur pedestrian dirasa panas untuk dilewati maka pejalan kaki akan enggan melewati jalur tersebut atau bergerak lebih cepat, kecuali di sekitaran jalur tersebut terdapat fasilitas yang banyak digunakan orang untuk sekedar hiburan maupun dalam melengkapi kehidupan.

\section{Referensi}

Anthonius N. Tandal, I. P. (2011). Arsitektur Berwawasan Perilaku (Behaviorisme). Media Matrasain, Vol 8. David Sucher, 1995, City Comfort, City Comforts Press, Scattle.

Diliawan, Y. B. (2003). Jalur Pedestrian Pada Sentra Perdagangan Elektronika Dan Onderdil Kendaraan

Ditinjau Dari Perilaku Pengguna. Semarang: Universitas Diponegoro.

Gideon Giovany, 1977, Human Aspect of Urban Form. Oxford: Pergamon Press

Gota S., Herbert G.F., Alvin A.M. and Sophie S.P. 2010. Walkability Survey in Asian CitiesManila: Asian Development Bank

Hantono, D., Butudoka, Z., Prakoso, A. A., \& Yulisaksono, D. (2019). Adaptasi Seting Ruang Pasar Jiung Terhadap Kehadiran Pasar Temporer Di Jalan Kemayoran Gempol Barat Jakarta. Jurnal Arsitektur ZONASI, 2(2), 75. https://doi.org/10.17509/jaz.v2i2.13628

Indraswara, M. S. (2006). Kajian Perilaku Pejalan Kaki Terhadap Pemanfaatan Jembatan Penyeberangan. ENCLOSURE, Volume 5 No. 2. 
Ischak, M., Setioko, B., \& Gandarum, D. N. (2018). Peran Place Identity Dalam Menciptakan Community Resiliance. Jurnal Arsitektur Zonasi, 1(2), 77-86. https://doi.org/http://10.17509/jaz.v1i2.12254

Nuqul, F.L., 2005, Pengaruh Lingkungan terhadap Perilaku Manusia studi terhadap Perilaku Penonton Bioskop, PSIKOISLAMIKA: Jurnal Psikologi dan Psikologi Islam 2 (2).

Permen ATR/BPN No. 16 tahun 2017, Pedoman Pengembangan Kawasan Berorientasi Transit

Rini Darmawant, D. (2011). Keragaman Perilaku Pengguna Trotoar Yang Berpengaruh Terhadap

Kenyamanan Dan Keamanan Pejalan Kaki Studi Kasus : Di Sepanjang Jalan Simanjuntak

Gondokusuman Yogyakarta.

Rona Panduri dan Djoko Suwandono, 2015, Perilaku Masyarakat dalam Penggunaan Jalur Pedestrian di Koridor Jalan Prof. H. Soedarto, S.H., Jurnal Tekni PWK, Volume 4 Nomor 2.

Shirvani, Hamid, 1985, The Urban Design process, Van Nostrand Reinhold Company, New York

Siregar, N. L. (n.d.). Pola Pergerakan Pengguna Kereta Api Sebagai Dasar Pengembangan Kawasan Tod (Studi Kasus : Stasiun K.A Medan). 2015.

Siti Nurjanah Ahmad, T. S. (2013). Tinjauan Perilaku Pejalan Kaki Dan Penyeberang Jalan Pada Kawasan Fakultas Pertanian Universitas Haluoleo. Jurnal Stabilita, 277.

Spreiregen, Paul D., 1965, Urban Design: The Architecture of Town and Cities, New York: Mc Graw Hill Book Company.

Sudhir Gota, H. G. (2010). Walkability Surveys In Asian Cities. Ictct.

Utermann, RK., 1984, Accommodating the Pedestrian, van Nostrand Reinhold Company

Widodo, M. (2001). Jalur Pejalan Kaki Jalan Pandanaran Semarang. Semarang: Universitas Diponegoro. 